\title{
Expression of M Protein from LP02/C Equine Arteritis Virus Inhibits Growth of Escherichia Coli M15-pQE30 System
}

\author{
Germán Ernesto Metz ${ }^{1,2, a^{*}}$, María Mercedes Abeyáa ${ }^{1,2, b}$, María Soledad Serena $^{1,2}$, Carlos Javier Panei ${ }^{1,2}$, Silvina Díaz ${ }^{2,3}$ and María Gabriela \\ Echeverría $^{1,2}$ \\ ${ }^{1}$ Virology, Faculty of Veterinary Sciences, National University of La Plata, La Plata, Argentina \\ ${ }^{2}$ Members of CONICET (Scientific Research Council), Argentina \\ ${ }^{3}$ Faculty of Veterinary Sciences, Instituto de Genética Veterinaria (IGEVET), National University of La Plata, La Plata, Argentina \\ a,b Both authors contributed equally to this work
}

\begin{abstract}
Our objective was to obtain Equine Arteritis Virus M protein in prokaryotic system to test it as immunogen. LP02/C Equine Arteritis Virus cDNA was used as template to obtain and clone this protein. Equine Arteritis $\mathrm{M}$ protein was cloned in the expression vector pQE30 and the recombinant plasmid pQE30/M was transformed in Escherichia Coli M15 cells. The OD 60 values of the IPTG-induced M15-pQE30/M culture showed an inhibition of the kinetics growth compared with the non-induced M15-pQE30/M and positive M15-pQE40/DHFR cultures. Several factors such as growth temperature, IPTG concentration and different inductors were analyzed but any of them showed an improvement in protein expression. Instead of $E$. coli M15strain, a new strain ( $E$. coli BL21) was used and transformed with the pQE30/M. This resolved in part the growth inhibition observed in E. coli M15 cells, but no the recovery yield of the protein. So, as all gene products that affect cells kinetics growth are considered to be toxic, we argue that the lower yields in M protein recovery could be attributed to an associated toxicity of $\mathrm{EAV}-\mathrm{M}$ protein from LP02/C strain in this expression system.
\end{abstract}

\section{Introduction}

Equine Viral Arteritis is a respiratory and reproductive horse disease caused by Equine Arteritis Virus (EAV) and it was first isolated in Ohio, USA, in 1953 [1,2]. It has been classified as a member of the Arteriviridae family, Nidovirales order, and grouped together with lactate dehydrogenase-elevating virus, porcine reproductive and respiratory syndrome virus (PRRSV), and simian hemorrhagic fever virus [3].

EAV is a small enveloped virus with a positive sense and singlestranded RNA genome of $12.7 \mathrm{~kb}$ which includes ten functional open reading frames (ORFs) [4]. ORFs $1 \mathrm{a}$ and $1 \mathrm{~b}$ encode two replicase polyproteins [3] and the remaining eigth ORFs (2a, 2b, and 3 to 7) encode the structural proteins of EAV. The EAV structural proteins include five membrane glycoproteins (GP), GP2, GP3, GP4, GP5, and OF5a protein, encoded by ORFs $2 b, 3,4,5$ and $5 a$ respectively; two unglycosylated membrane proteins, $\mathrm{E}$ and $\mathrm{M}$, encoded by ORFs $2 \mathrm{a}$ and 6; and the remaining ORF 7 encoded for phosphorylated nucleocapsid protein $\mathrm{N}$ [5-7].

The predicted ORF 6 product has a molecular weight of approximately $18 \mathrm{kDa}$. It lacks $\mathrm{N}$-glycosylation sites, and it contains five methionines and one cysteine. The only cysteine present in the $\mathrm{N}$ terminal of the M protein, Cys 8, is linked with one of the cysteines present in the ectodomain of the membrane glycoprotein GP5 (Cys 34) and forms disulfide-linked heterodimers (M/GP5) [8].

The $\mathrm{M}$ protein is the most conserved structural protein in EAV and in PRRSV $[9,10]$. It has been reported the tendency of M protein to aggregate and form homodimers in EAV and in PRRSV, but this conformation of $\mathrm{M}$ protein was not incorporated in the mature virions. This tendency to aggregation was also found in Coronavirus family [9]. The structure, the membrane-associated function and the hidrofobicity profile of the $\mathrm{M}$ protein resemble all members of the Nidovirales order [11].

The $\mathrm{M}$ protein was the most consistently recognized EAV protein recognized by seroneutralization positive sera from naturally and experimentally infected horses [12-14]. The deletion of the N-terminal 87 amino acids did not abolish the immune reactivity of the protein, demonstrating the antigenicity of the C-terminal region (amino acids 88 to 162$)$ [15].

In this work, we aimed to produce and recover EAV-M protein to test it as immunogen. Nevertheless, we provide a detailed analysis that the expression of EAV-M protein in the prokaryotic system E.coli M15 strain and $\mathrm{pQE} 30$ vector has an inherent toxicity and consequence produce a marked inhibition in cell growth that could not be reverted.

Correspondence to: Dr. Germán Ernesto Metz, Assistant Researcher from CONICET-Argentina Virology, Faculty of Veterinary Sciences, National University of La Plata, La Plata, Argentina, Tel: +54 0221 4824956; Fax: +54 0221 4824956; E-Mail: germanmetz@fcv.unlp.edu.ar

Key words: equine arteritis virus, LP02/C strain, M protein, Escherichia coli M15 ( $p R E P 4), p Q E 30$ expression system

Received: April 10, 2017; Accepted: April 25, 2017; Published: April 27, 2017 


\section{Material and methods}

\section{Obtaining of ORF6 gene from LP02/C and clone into PQE30 plasmid}

Viral RNA from the Argentinean LP02/C EAV strain was extracted from infected rabbit kidney(RK13) cell cultures [16]. The EAV RNA was reversely transcribed and amplified using Moloney Murine Leukemia Virus Reverse Transcriptase (Promega, Madison, Wisconsin, USA) and Random Hexamers (New England Biolabs, Madison, Wisconsin, USA). The EAV ORF 6 encoding region was amplified using the cDNA obtained as a template. A pair of primers was designed including a recognition site sequence for BamHI and SacI restriction enzymes to allow the subsequent cloning into the $\mathrm{QEE} 30$ expression vector (Qiagen). The sense and antisense primers designed for pQE30 cloning were: pQEMBamHI 5'-GGGGATCCGGAGCCATAGATTCATTTTG-3' (nucleotides 11903 to 11922) and pQEMSacI 5'-TTGAGCTCCGCAGTAGGTCATTGTAGCTT-3' (nucleotides 12377 to 12398). The underlined nucleotides were the restriction enzyme sites added to the primers for the subsequent digestion. The EAV ORF 6 PCR product (511bp) was purified with the Wizard SV Gel and PCR Clean-Up System (Promega), digested with BamHI and SacI restriction enzymes and cloned into the pQE30 expression vector previously digested with the same restriction enzymes.

\section{Transformation of pQE30/M in Escherichia coli M15 (pREP4)}

Competent E. coli M15 (pREP4) were transformed with pQE30/M construction. Briefly, competent cell tube was incubated on ice for 30 minutes. Then cells were incubated in a $42^{\circ} \mathrm{C}$ water bath for 60 seconds followed incubation on ice for 2 minutes. It was added $0,9 \mathrm{ml}$ of preheated SOC medium to the tube and incubated at $37^{\circ} \mathrm{C}$ for 1 hour with shaking at $250 \mathrm{rpm}$. Finally, $200 \mu \mathrm{l}$ of the transformation mixture was seed in LB agar plates containing antibiotics $(100 \mu \mathrm{l} / \mathrm{ml}$ ampicillin and $25 \mu \mathrm{l} / \mathrm{ml}$ kanamycin -pREP4 confer the kanamycin resistance). Colonies were analyzed by PCR with $\mathrm{pQE}$ Sequencing Primer Set from The QIAexpressionist (Qiagen) to detect the EAV ORF6. PCR from pQE30 backbone sized $335 \mathrm{bp}$. Finally, positives PCR clones (pQE30 $335 b p+$ EAV ORF 6511 bp) were recovered and purified by miniprep.

\section{Induction of EAV-M protein in E. coli M15 (pREP4) and} evaluated factors

Initially, for expression of EAV-M protein, E. coli M15 (pREP4) transformed with the recombinant plasmid pQE30/M (M15pQE30/M) were propagated in Luria Bertani (LB) medium with 100 $\mu \mathrm{g} / \mathrm{ml}$ ampicillin and $25 \mu \mathrm{g} / \mathrm{ml}$ kanamycin at $37^{\circ} \mathrm{C}$ with shaking. When M15-pQE30/M culture grew to logarithmic phase - optical density at $600 \mathrm{~nm}\left(\mathrm{OD}_{600}\right)$ of $0.6-, 1 \mathrm{mM}$ of Isopropyl $\beta$-D-1-thiogalactopyranoside (IPTG) was added to induce expression of the EAV-M protein. We have used pQE40-DHFR (Qiagen) expressing the Dihydrofolate Reductase (DHFR), a $26 \mathrm{kDa}$ protein, as positive expression control. Cells were monitored spectrophotometrically both for induced and non-induced cultures.

We evaluated different factors that affect protein expression such as incubation temperatures $\left(4^{\circ} \mathrm{C}, 30^{\circ} \mathrm{C}\right.$ and $\left.37^{\circ} \mathrm{C}\right)$, IPTG concentrations ( $1 \mathrm{mM}$ and $0.1 \mathrm{mM})$, antibiotic concentration, lactose as inductor and other E. coli strain BL21(pREP4).

\section{Polyacrylamide gel and Western Blot analysis}

Samples from each culture conditions were analysed on sodium dodecyl sulphate polyacrylamide gel electrophoresis (SDS-PAGE) and the gel stained with Coomassie brilliant blue R-250.
Western Blot we revealed using polyclonal EAV positive antibodies and monoclonal anti-histidine antibodies (GE Healthcare, Freiburg, Germany). As secondary antibodies, peroxidase-conjugated anti-horse and anti-mouse were used (Sigma Chemical, St. Louis, Missouri, USA).

\section{Results and discussion}

\section{Minipreps of $\mathrm{pQE30/M}$ recombinant plasmid}

Twelve positive clones grown in LB plates with antibiotics were picked and verified the presence of EAV ORF6 by PCR with pQE Sequencing Primer Set from The QIAexpressionist (Qiagen). Nine of the colonies analyzed evidence the presence of EAV ORF6 (PCR product of $846 \mathrm{bp}$ ) (Figure 1). These positive clones carrying recombinant plasmids $\mathrm{pQE} 30 / \mathrm{M}$ were recovered by miniprep and the DNA sequencing of five positive clones confirmed that the EAV ORF 6 sequence was in frame in the pQE30 expression vector (data not shown).

\section{Evaluation of EAV-M protein expression in E. coli M15 (pREP4) at $37^{\circ} \mathrm{C}$ induced with $1 \mathrm{mM}$ of IPTG}

A culture of M15-pQE30/M was induced to express EAV-M protein using $1 \mathrm{mM}$ of IPTG and $37^{\circ} \mathrm{C}$. The $\mathrm{OD}_{600}$ values of the induced culture showed an inhibition of the kinetics growth compared with the non-induced M15-pQE30/M and positive M15-pQE40/DHFR culture at all the time intervals monitored (Table 1 and Figure 2a).

Samples from each culture were analyzed on sodium dodecyl sulphate-polyacrilamide gel electrophoresis (SDS-PAGE) and the gel stained with Coomassie brilliant blue R-250 showed the expression of the control DHFR protein $(26 \mathrm{kDa})$, although it did not evidence any band at the molecular weight of the EAV-M protein $(18 \mathrm{kDa})$ in the induced culture (data not shown). However, the presence of a band of the expected molecular size corresponding to EAV-M protein was revealed through Western Blot using polyclonal EAV positive antibodies and monoclonal anti-histidine antibodies (Figure 3a). The

Table 1. The $\mathrm{OD}_{600}$ values of the M15-pQE30/M induced and non-induced, and induced M15-pQE40/DHFR at all the intervals times monitored. Time 0 refers to the initiation of induction. The number in brackets indicate the dilution of the sample prior to measurement Conditions of induction: $1 \mathrm{mM}$ IPTG, $100 \mu \mathrm{g} / \mathrm{ml}$ ampicillin and $25 \mu \mathrm{g} / \mathrm{ml}$ kanamycin, $37^{\circ} \mathrm{C}$.

\begin{tabular}{|c|c|c|c|}
\hline Time & $\begin{array}{c}\text { M15-pQE30/M } \\
\text { Non-induced }\end{array}$ & $\begin{array}{c}\text { M15-pQE30/M } \\
\text { Induced }\end{array}$ & $\begin{array}{c}\text { M15-pQ40/DHFR } \\
\text { Induced }\end{array}$ \\
\hline 0 & 0.55 & 0.620 & 0.539 \\
\hline 1 & 0.745 & 0.612 & 0.685 \\
\hline 2 & 0.961 & 0.587 & 0.835 \\
\hline 3 & $0.589(1 / 2)$ & 0.510 & $0.521(1 / 2)$ \\
\hline 4 & $0.732(1 / 2)$ & 0.495 & $0.624(1 / 2)$ \\
\hline 5 & $0.798(1 / 2)$ & 0.498 & $0.687(1 / 2)$ \\
\hline 6 & $0.821(1 / 2)$ & 0.492 & $0.704(1 / 2)$ \\
\hline
\end{tabular}

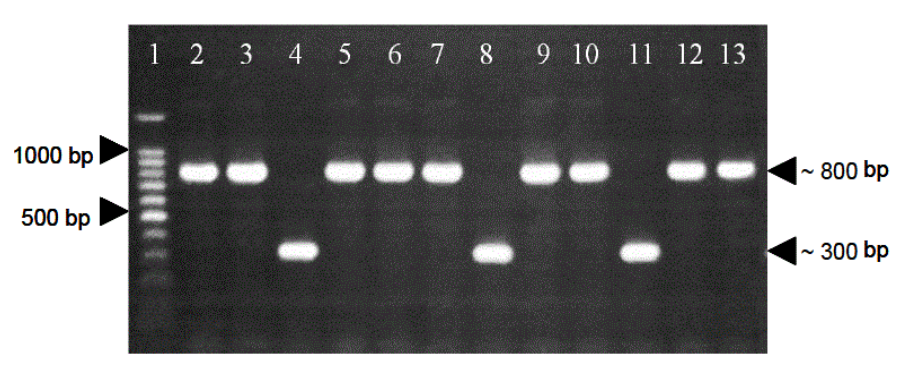

Figure 1. PCR using pQE sequencing primer set on transformed colonies of E. ColiM15 Line 1:100bp ladder. Lines 2, 3, 5, 6, 7, 9, 10,12, 13: positive colonies carrying the insert of interest (M15-pQE30/M). Lines 4, 8, 11: negative colonies (M15-pQE30). 

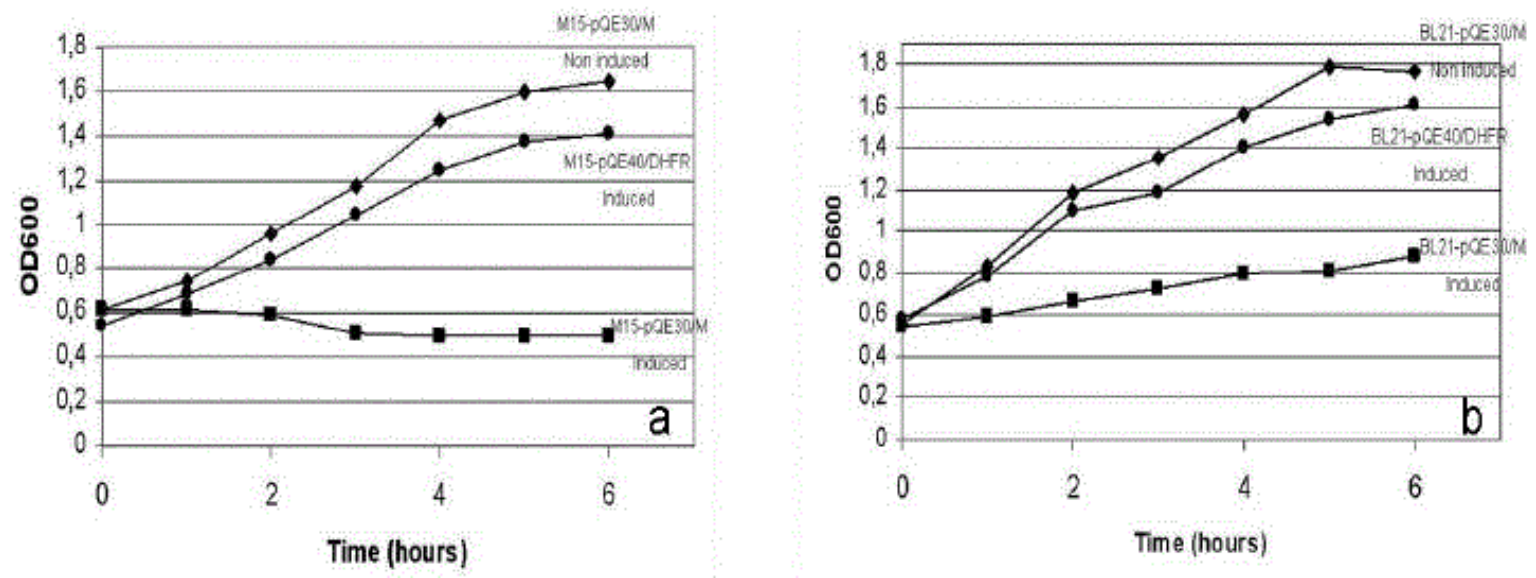

Figure 2. a) Growth rate kinetics between M15-pQE30/M induced and non-induced and M15-pQE40/DHFR induced. b) Comparison of growth rate kinetics between BL21-pQE30/M induced and non-induced and BL21-pQE40/DHFR induced..

anti-histidine blotting showed two protein bands at approximately 18 $\mathrm{kDa}$ and $35 \mathrm{kDa}$, indicating the formation of $\mathrm{M} / \mathrm{M}$ dimmer. So, the identification of EAV-M protein only by Western Blot evidenced the higher sensitivity of this technique in the detection of lower protein concentrations [17].

\section{Analysis of different factors that influence protein expression in E. coli}

Several factors could influence protein expression in prokaryotic systems $[18,19]$. The reduction of culture growth temperature allows more time for protein folding by diminishing the growth kinetics of cultures and, consequently, proteins expression. As a first analysis, the culture growth temperature was reduced to $30^{\circ} \mathrm{C}$; prior to the IPTG induction, all cultures growth were slightly less than the growth at $37^{\circ} \mathrm{C}$. After IPTG induction, the non-induced and positive cultures maintained these reduction in growing compared with cultures at $37^{\circ} \mathrm{C}$ but their growth was not limited. However, induced M15pQE30/M culture showed the same growth inhibition as presented at $37^{\circ} \mathrm{C}$. Chirnside, et al. [20], obtained improvements in EAV protein expression in prokaryotic systems when the temperature was reduced. Nevertheless, no improvements were obtained in this work.

IPTG is a sulfur toxic molecule at high concentration because it could not be metabolized by cells. IPTG concentration was decreased to $0.1 \mathrm{mM}$ but M15-pQE30/M culture was still limited in their growth. By contrast, some authors reported the addition of $2 \mathrm{mM}$ of IPTG for the induction of expression of EAV-GP5 protein in M15-pQE9 without having any obstacle in the recovery of this protein [21]. When IPTG was replaced with lactose as inductor, M15-pQE30/M culture showed the same inhibition pattern indicating that the inhibition effect was not attributed to the addition of IPTG.

Plasmids impose a metabolic stress on their hosts, giving an advantage in culture to plasmid-free cells. The inefficient selection pressure by antibiotics could be responsible for the loss of plasmid in successive bacteria replication [22]. The addition of twofold ampicillin concentration into the culture as positive selector did not improve the protein expression yield.

E. coli BL21 strain harboring $\mathrm{pREP} / 4$ was the new strain selected for transformation with the construction previously obtained in order to analyze the inhibition conditions observed in E. coli M15 strain. After the transformation, BL21-pQE30/M obtained was propagated at the same initial conditionsas M15-pQE30/M cultures (1 mM IPTG, 100
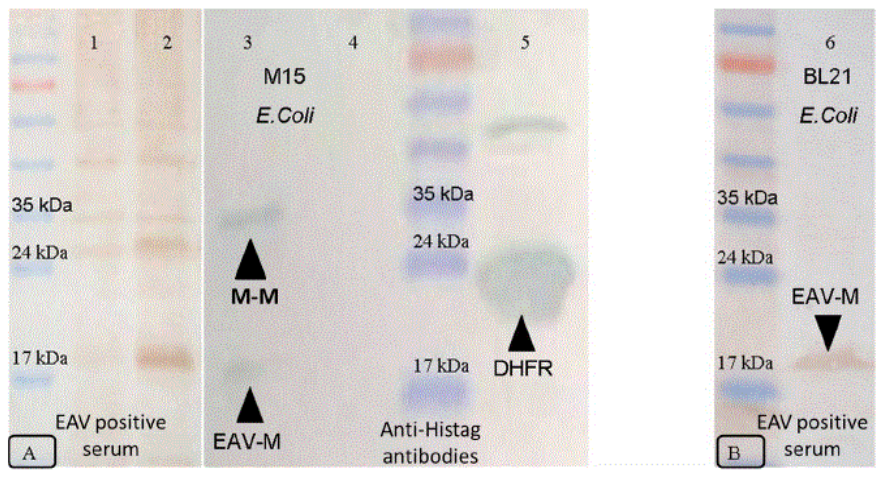

Figure 3. A) Western Blot analysis of expression of EAV-M protein inE.ColiM15 strain. Line 1: non-induced M15-pQE30/M with polyclonal EAV positive serum. Line 2: induced M15-pQE30/M withpolyclonal EAV positive serum. Line 3: induced M15-pQE30/M with monoclonal anti-histidine. Line4: non-induced M15-pQE30/M with monoclonal antihistidine. Line 5: induced M15-pQE40/DHFRwith monoclonal anti-histidine. B) Line 6: BL21-pQE30/M induced with monoclonal anti-histidine. Allsamples were taken at $\mathrm{t}=6 \mathrm{~h}$ of the experience and all were seed in non-reducing conditions.

$\mu \mathrm{g} / \mathrm{ml}$ ampicillin and $25 \mu \mathrm{g} / \mathrm{ml}$ kanamycin, $37^{\circ} \mathrm{C}$ ). The values of $\mathrm{OD}_{600}$ of the induced BL21-pQE30/M culture showed a slight growth increase compared with the induced M15-pQE30/M culture (Table 2 and Figure $2 b)$. In this new system, the inhibition of bacteria growth was solved in part because the OD600 values rose 0.3 point after adding IPTG. As in M15/pREP4, the expression of EAV M protein in BL21/pREP4 was detected only in Western Blot (Figure $3 \mathrm{~b}$ ) but no in polyacrylamide gels. We observed only a band of $18 \mathrm{kDa}$ and no dimer M/M protein was detected in E. coli BL21 as compared with E. coli M15.

In this work, several factors were analyzed in the EAV-M expression in E. coli M15 cells and none of them showed an improvement in protein expression. As all gene products that affect cells kinetics growth are considered as toxic, we argue that the lower yields in EAV-M recovery could be attributed to an associated toxicity of EAV-M protein expression in this system or also to instability of the construction, as other expression system of EAV-M protein did not evidence this growth inhibition [15,23,24].

By a simple set of experiments we provided evidence about the inhibition of growth rate in E. coli M15 carrying the recombinant plasmid $\mathrm{pQE} 30 / \mathrm{M}$ and expressing EAV M protein. We evidenced a higher inhibition of growth in these cells rather than E. coli BL21. Also, our investigation revealed that Western Blot using EAV polyclonal 
Table 2. The $\mathrm{OD}_{600}$ values of the BL21-pQE30/M induced and non-induced and induced BL21-pQE40/DHFR at all the intervals times monitored. Time 0 refers to the initiation of induction. The number in brackets indicate the dilution of the sample prior to measurement Conditions of induction: $1 \mathrm{mM}$ IPTG, $100 \mu \mathrm{g} / \mathrm{ml}$ ampicillin and $25 \mu \mathrm{g} / \mathrm{ml}$ kanamycin, $37^{\circ} \mathrm{C}$

\begin{tabular}{|c|c|c|c|}
\hline Time & $\begin{array}{c}\text { BL21-pQE30/M } \\
\text { Non-induced }\end{array}$ & $\begin{array}{c}\text { BL21-pQE30/M } \\
\mathbf{1 m M}\end{array}$ & $\begin{array}{c}\text { BL21-pQ40/DHFR } \\
\mathbf{1 m M}\end{array}$ \\
\hline 0 & 0.559 & 0.549 & 0.578 \\
\hline 1 & 0.831 & 0.597 & 0.792 \\
\hline 2 & 1.190 & 0.670 & 1.097 \\
\hline 3 & $0.679(1 / 2)$ & 0.732 & $0.595(1 / 2)$ \\
\hline 4 & $0.781(1 / 2)$ & 0.796 & $0.704(1 / 2)$ \\
\hline 5 & $0.898(1 / 2)$ & 0.813 & $0.767(1 / 2)$ \\
\hline 6 & $0.442(1 / 4)$ & 0.889 & $0.401(1 / 4)$ \\
\hline
\end{tabular}

serum showed a band corresponding to dimer M/M protein in E. coli M15 (Figure 3a) that was not identified in E. coli BL21. Although more research is required for a definitive conclusion, the associated toxicity could be linked to the hydrophobic region of EAV-M protein, which prompts us to suggest that toxic effects are related to the general stress responses elicited against misfolding prone protein domains [25].

The previous evidence of $\mathrm{M}$ protein dimerization in M15 cells could be another causative explanation for this toxicity. Jeronimo and Archambault [15] have produced intact and truncated $M$ fusion proteins in prokaryotic system using Bucyrus strain. The lower degree of protein expression for wild type $\mathrm{M}$ protein and the larger $\mathrm{M}$ protein fragment was believed to be related to the predicted low solubility index of the $\mathrm{M}$-protein $\mathrm{N}$ terminus, as suggested by the predominant presence of three highly hydrophobic domains in this region of the protein.

The hydropathy profile of the ORF 6 protein from Equine Arteritis Virus is remarkably similar to that of the membrane protein of Coronavirus $[9,26]$. In this relation, the expression of the $M$ protein from porcine epidemic diarrhoea virus, which belongs to the Nidovirales order and the Coronavirus family, was found to damage the cell wall, producing growth inhibition [15]. All previous report of $M$ protein expression from EAV was done using Bucyrus strain or related strain, all belonging to the group of American strains. This is the first report of the use of EAV LP02/C Argentinean strain, grouped together with all Argentinean strains in European EAV cluster [16]. In spite of this cluster difference, the sequence of both EAV-M Bucyrus and LP02/C strains has high similarity values when both sequences were compared by Blast search, so this difference may not be in relation with the lower yield of culture growth.

\section{Conclusion}

E. coli is a host of choice for expression prokaryotic proteins and from diverse eukaryotes non-glycosylated proteins. Nevertheless, the expression of some of these proteins has shown an inhibitory effect on the E. coli growth. In such cases, the expression yields are severely diminished or sometimes abolished. The expression can fail because the putative protein generated may not be the same in conformation, folding and post traductional modification, compared with the viral protein. All the parameters must be studied and fixed in each particular expression system [18].

\section{Acknowledgments}

The assistance of Ms. A. Conde and Mr. C. Leguizamon is highly acknowledged. This investigation was supported by Incentivos docentes del Laboratorio de Virología Facultad de Ciencias Veterinarias. Universidad Nacional de La Plata. Argentina. (FCV-UNLP).

\section{Conflict of interest}

The authors declare that they have no conflict of interest.

\section{References}

1. Bryans JT, Crowe ME, Doll ER, Mccollum WH (1957) Isolation of a filterable agent causing arteritis of horses and abortion by mares; its differentiation from the equine abortion (influenza) virus. Cornell Vet 47: 3-41. [Crossref]

2. Timoney PJ, McCollum WH (1993) Equine viral arteritis. Vet Clin North Am Equine Pract 9: 295-309. [Crossref]

3. Snijder EJ (2001) Arteriviruses.In Knipe DM, HowleyPM (Eds) Fields Virology. Lippincott Williams and Wilkins, Philadelphia, PA, pp: 1205-1220.

4. Snijder EJ, Meulenberg JJ (1998) The molecular biology of arteriviruses. J Gen Virol 79: 961-979.[Crossref]

5. Snijder EJ, van Tol H, Pedersen KW, Raamsman MJ, de Vries AA (1999) Identification of a novel structural protein of arteriviruses. J Virol 73: 6335-6345.[Crossref]

6. Wieringa R, de Vries AA, Raamsman MJ, Rottier PJ (2002) Characterization of two new structural glycoproteins, GP(3) and GP(4), of equine arteritis virus. $J$ Virol 76 : 10829-10840.[Crossref]

7. Firth AE, Zevenhoven-Dobbe JC, Wills NM, Go YY, Balasuriya UB, et al. (2011) Discovery of a small arterivirus gene that overlaps the GP5 coding sequence and is important for virus production. J Gen Virol 92: 1097-1106.[Crossref]

8. Snijder EJ, Dobbe JC, Spaan WJ (2003) Heterodimerization of the two major envelope proteins is essential for arterivirus infectivity. $J$ Virol 77: 97-104.[Crossref]

9. de Vries AA, Chirnside ED, Horzinek MC, Rottier PJ (1992) Structural proteins of equine arteritis virus. $J$ Virol 66: 6294-6303.[Crossref]

10. Meulenberg JJ (2000) PRRSV, the virus. Vet Res 31: 11-21.[Crossref]

11. Cavanagh D (1997) Nidovirales: a new order comprising Coronaviridae and Arteriviridae. Arch Virol 142: 629-633.[Crossref]

12. Hedges JF, Balasuriya UB, Ahmad S, Timoney PJ, McCollum WH, et al. (1998) Detection of antibodies to equine arteritis virus by enzyme linked immunosorbant assays utilizing $\mathrm{G}(\mathrm{L}), \mathrm{M}$ and $\mathrm{N}$ proteins expressed from recombinant baculoviruses. $J$ Virol Methods 76: 127-137.[Crossref]

13. MacLachlan NJ, Balasuriya UB, Hedges JF, Schweidler TM, McCollum WH, et al. (1998) Serologic response of horses to the structural proteins of equine arteritis virus. $J$ Vet Diagn Invest 10: 229-236.[Crossref]

14. Wagner HM, Balasuriya UB, James MacLachlan N (2003) The serologic response of horses to equine arteritis virus as determined by competitive enzyme-linked immunosorbent assays (c-ELISAs) to structural and non-structural viral proteins. Comp Immunol Microbiol Infect Dis 26: 251-260.[Crossref]

15. Jeronimo C, Archambault D (2002) Importance of M-protein C terminus as substrate antigen for serodetection of equine arteritis virus infection. Clin Diagn Lab Immunol 9: 698-703.[Crossref]

16. Echeverría MG, Díaz S, Metz GE, Serena MS, Panei CJ, et al. (2007) Genetic typing of equine arteritis virus isolates from Argentina. Virus Genes 35: 313-320.[Crossref]

17. Sasse J, Gallagher SR (2009) Staining proteins in gels. Curr Protoc Mol Biol Chapter 10: Unit 10.[Crossref]

18. Sørensen HP, Mortensen KK (2005) Advanced genetic strategies for recombinant protein expression in Escherichia coli. J Biotechnol 115: 113-128.[Crossref]

19. Rosano GL, Ceccarelli EA (2014) Recombinant protein expression in Escherichia coli advances and challenges. Front Microbiol 5: 172.[Crossref]

20. Chirnside ED, de Vries AA, Mumford JA, Rottier PJ (1995) Equine arteritis virusneutralizing antibody in the horse is induced by a determinant on the large envelope glycoprotein GL. J Gen Virol 76: 1989-1998.[Crossref]

21. Castillo-Olivares J, de Vries AA, Raamsman MJ, Rottier PJ, Lakhani K, et al. (2001) Evaluation of a prototype sub-unit vaccine against equine arteritis virus comprising the entire ectodomain of the virus large envelope glycoprotein $(\mathrm{G}(\mathrm{L}))$ : induction of virus-neutralizing antibody and assessment of protection in ponies. J Gen Virol 82 2425-2435.[Crossref]

22. Glick BR (1995) Metabolic load and heterologous gene expression. Biotechnol Adv 13 247-261.[Crossref] 
23. Go YY, Wong SJ, Branscum AJ, Demarest VL, Shuck KM, et al. (2008) Development of a fluorescent-microsphere immunoassay for detection of antibodies specific to equine arteritis virus and comparison with the virus neutralization test. Clin Vaccine Immunol 15: 76-87.[Crossref]

24. Kheyar A, Martin S, St-Laurent G, Timoney PJ, McCollum WH, et al. (1997) Expression cloning and humoral immune response to the nucleocapsid and membrane proteins of equine arteritis virus. ClinDiagn Lab Immunol 4: 648-652. [Crossref]
25. Fernández G, Vera A, Villaverde A, Martínez MA (2007) Analysis of recombinant protein toxicity in E. coli through a phage lambda-based genetic screening system. Biotechnol Lett 29: 1381-1386.[Crossref]

26. Rottier PJ, Welling GW, Welling-Wester S, Niesters HG, Lenstra JA, et al. (1986) Predicted membrane topology of the coronavirus protein E1. Biochemistry 25: 13351339. [Crossref]

Copyright: (C2017 Metz GE. This is an open-access article distributed under the terms of the Creative Commons Attribution License, which permits unrestricted use, distribution, and reproduction in any medium, provided the original author and source are credited. 